\title{
Sansningens phaneroscopy
}

\author{
K.E. Løgstrups opfattelse af sansningen udlagt gennem \\ C.S. Peirces kategorilære
}

Lektor, ph.d. Jesper Tang Nielsen

Abstract: The Danish theologian and philosopher K.E. Løgstrup has presented an original theory of sensation. From a phenomenological perspective, sensation is not receptive but without distance, he claims. By introducing C.S. Peirces categories Firstness, Secondness and Thirdness, it is argued that Løgstup's understanding of sensation coheres with parts of Peirce's so called phaneroscopy. The lack of distance in sensation corresponds to Firstness. As a corollary, Løgstrup's theory can be understood within Peirce's more comprehensive phenomenological approach to reality. Finally, some perspectives for Løgstrup's religious interpretation of sensation are discussed.

Key words: Sensation - phenomenology - K.E. Løgstrup - C.S. Peirce.

Udgiverne til sidste posthumt udgivne bind af K.E. Løgstrups metafysik ${ }^{1}$ citerer Løgstrup for, at han i sansningens fænomen fandt "den akse, som det hele drejer sig om" (Løgstrup 1984, 10). Analysen af sansningen er da også den afgørende forudsætning for bogens ide om 'indfældetheden i universet' og den 'religiøse tydning' deraf. Samtidig er denne analyse vel den mest kontroversielle i Løgstrups sene værk, eftersom den på den ene side vil hævde at have filosofisk og fænomenologisk gyldighed, og på den anden side kan forekomme fremmed og fortænkt. Årsagen er Løgstrup ganske bevidst om. Hans teori gør nemlig op med en

opfattelse af sansningen, der behersker os med en sådan selvfølgelighed, at vi end ikke tænker på at sætte spørgsmålstegn ved den og det til trods for at det er oplagt, at den er en vrangforestilling. Vi

1. K.E. Løgstrup, Ophav og omgivelse. Betragtninger over historie og natur. Metafysik III, København: Gyldendal 1984. 
finder, at sansningen er receptiv, men det er den ikke, den er afstandsløs (Løgstrup 1984, 14f)

Man kunne forestille sig, at en så innovativ tese ville afføde mængder af filosofiske analyser, der be- eller afkræfter den radikale forståelse, og bjerge af idehistoriske redegørelser, der placerer den i en særlig fænomenologisk tradition. Indtil videre har det ikke været tilfældet. Bortset fra påpegningen forbindelsen til Hans Lipps ${ }^{2}$ og fremvisningen af den kritiske videreudvikling af Martin Heidegger ${ }^{3}$ er Løgstrups opfattelse ikke sat i sammenhæng med andre teorier. Hvis man har sammenlignet med andre fænomenologer, har det altid været for at vise, hvorledes Løgstrup adskiller sig fra disse. Det er tilfældet i Svend Andersens efterskrift til Ophav og Omgivelse, hvor Løgstrup modstilles Edmund Husserl (Løgstrup 1984, 292f), og i Jakob Wolfs sammenligning med Maurice Merleau-Ponty. ${ }^{4}$ Dette forhold er så meget desto mere forunderligt, da de fleste kommentatorer er enige om, at Løgstrups teori om sansningen hører til blandt de vanskeligere dele $\mathrm{i}$ hans forfatterskab.

Fraværet af fænomenologiske sidestykker kan naturligvis være begrundet i, at Løgstrups opfattelse er enestående. Det har Løgstrup sikkert ment, og det er hans eksegeter tilsyneladende enige i. ${ }^{5}$ Imidlertid kan årsagen også være, at man udelukkende har koncentreret sig om kontinentale filosoffer og ikke har set til den amerikanske gren af fænomenologien. Hos dennes egenartede og originale repræsentant, C.S. Peirce, finder man en fænomenologisk opfattelse, der

2. Jakob Wolf, Den farvede verden. Om Goethes farvelare, Hans Lipps' fenomenologi og K.E. Løgstrups religionsfilosofi, København: Munksgaard 1990, 208-210.

3. Hans-Jørgen Schanz, Forandring og balance. Refleksioner over metafysik og modernitet, Aarhus: Modtryk 1990, 164-166.

4. Jakob Wolf, "Hvad er fænomenologi?", i Mickey Gjerris og Jakob Wolf (red.), Spor $i$ sandet. Bidrag til forståelse af K.E. Logstrups forfatterskab, København: Forlaget Anis 2002, 93-106; Jakob Wolf, “”Jeg går ind for metafysik med fuld musik.” Løgstrup og sansningen”, i David Bugge, Pia Rose Böwadt og Peter Aaboe Sørensen, Løgstrups mange ansigter, København: Forlaget Anis 2005, 79-92 (86f).

5. Jf. "At Løgstrup er af den opfattelse, at sansning er afstandsløs, er i sig selv originalt. Det er imidlertid en originalitet, der yderligere får et løft ved, at han hævder, at det er universet, og ikke omverdenen eller det værende, som er nærværende i den afstandsløse sansning." Schanz (1990), 160. 
kan belyse Løgstrups forestilling om sansningen. ${ }^{6}$ Når denne sammenstilling ikke umiddelbart forekommer indlysende, er det ikke blot, fordi Peirce var ret ukendt for Løgstrup, eller fordi han primært er reciperet som semiotiker, men også fordi han eksplicit lægger afstand til den traditionelle fænomenologiske tradition og betegner sin egen fænomenologi phaneroscopy. Alligevel er der slående lighedspunkter mellem de to, som kan klargøre visse af de kritiske punkter i Løgstrups teori og samtidig tolke den ind i en langt mere omfattende fænomenologisk forestillingsverden, end Løgstrup selv fremsætter. Det er denne artikels ærinde.

Indledningsvis vil der redegøres for Løgstrups teori om sansningen. Dernæst fremstilles forskningsdiskussionen i forbindelse med Løgstrups sansningsteori. Til slut følger afsnittet om Peirces phaneroscopy og hans lære om tre universelle kategorier, hvilket danner grundlag for en nytolkning af Løgstrups opfattelse af sansningen.

\section{Løgstrups sansning}

Sansningen er efter Løgstrups opfattelse ikke receptiv, som man er tilbøjelig til at tro. ${ }^{7}$ En sådan forestilling bevirker, at menneskets sansning konstitueres inden for kraniet. Omgivelserne leverer stimuli, som hjernen bearbejder, derfor er mennesket egentligt blot forbundet med naturen i kraft af det materiale, som mennesket forbruger. Konsekvensen er, at mennesket placeres på randen af universet (Løgstrup 1984, 30). Det er ikke deltagende deri, for det er ikke indlejret i dets processer. Tværtimod bringer denne opfattelse af sansningen mennesket på afstand af universet. Det befinder sig udenfor i en modtagende position, hvor det $\mathrm{i}$ en vis forstand konsumerer de påvirkninger, som universet sender det. Netop denne afstand mellem universet og mennesket udgør det grundlæggende problem. Mennesket forstår kun universet som omgivelse og ikke også som ophav. Af

6. Trond Skard Dokka bemærker i en redegørelse for "opplevelseskvaliteten" hos Peirce: "Både terminologisk og tankemessig foreligger det her et markant slektskab mellom Peirce og Løgstrup..." Trond Skard Dok$\mathrm{ka}$, A gjenkjenne den ukjente. Om menneskers mulighet for å kjenne Guden studie basert på Johannes-evangeliets tegnstof, Oslo 1989, 274 note 31; jf. 276 note 37. Mig bekendt er det første og hidtil eneste gang Løgstrup og Peirce sammenstilles. Nærværende artikel kan ses som et forsøg på at udfolde dette terminologiske og tankemæssige slægtskab.

7. Løgstrup anfører faktisk noget lignende i tilknytning til Immanuel Kant og i diskussion med Martin Heidegger. Løgstrup (1984), 223; jf. Svend Andersens efterskrift: Løgstrup (1984), 287. 
den grund er det afgørende for Løgstrup at gøre op med den afstand, som sansningen angiveligt skaber.

Som nævnt er Løgstrups opgør radikalt og originalt. Hans påstand er, at det er et vrangkompleks, at sansningen er receptiv. Tværtimod er den afstandsløs (Løgstrup 1984, 15). Således medfører sansningen i Løgstrups tolkning det stik modsatte af afstand; den indlejrer det sansende menneske i universet: "Med åndedræt og stofskifte er vi indlagte i naturens kredsløb, med vore sanser er vi indlagte i universet" (Løgstrup 1984, 11). Sansningen er det springende punkt i Løgstrups argumentation, for $\mathrm{i}$ hans tolkning overvinder den netop afstanden mellem mennesket og universet, som den i den gængse opfattelse etablerer.

Der kan være grund til at understrege, at Løgstrup naturligvis ikke benægter, at sansning fysiologisk og neurologisk set finder sted ved at ydre stimuli modtages af sensoriske organer og bearbejdes i hjernen. Men Løgstrup arbejder ikke naturvidenskabeligt. Hans påstand er, at sansningen fænomenologisk ikke tager sig således ud. Når mennesket sanser, oplever det ikke, at det modtager påvirkninger, som det bearbejder til sanseindtryk (Løgstrup 1984, 23). Sansning som fænomen er ganske anderledes, hævder Løgstrup, for den er afstandsløs.

Det hævdes gerne, at Løgstrups tolkning ikke er en umiddelbar genkendelig beskrivelse af sansningens fænomen. Hvad vil det sige, at sansningen er afstandsløs, og hvordan kan det påstås inden for en fænomenologisk tilgang? Begge spørgsmål er særligt vigtige i denne sammenhæng.

Problemerne ved at forstå sansningens afstandsløshed stammer ikke fra Løgstrups fremstilling deraf, for den er ganske klar. Uden omsvøb beskriver han, hvorledes sansningen ophæver afstanden mellem det sansede og den sansende:

Strengt taget viser sig intet i sansningen. I vor tilværelse tager det sig kun sådan ud, takket være at forstålsen kommer til. Forståelsen tilvejebringer den afstand, i hvilket det tager sig ud, som om det sansede viser sig i vor sansning. Men kunne vi - hvad vi ikke kan udelade forstålsen og alene være til i sansningen, ville vi afstandsløst være det sansede (Løgstrup 1984, 28).

Udlægningen af dette må være lige så radikal som udsagnet. Det betyder simpelt hen, at der ikke er afstand mellem den sansende og det sansede i sansningen. Kunne man se bort fra alle andre egenskaber ved den sansende end det, at han sanser, og kunne man abstrahere fra det sansedes kvaliteter ud over det, der sanses, ville forskellen mellem den sansende og det sansede forsvinde i sansningen. Først når den 
sansende også opfattes som en person, der sanser, og det sansede som et objekt, der sanses, indtræder forskellen og afstanden (Løgstrup 1984, 21). Sansningen selv indeholder ikke denne forskel, for den er afstandsløs.

Tænker man sansningen som enheden af den sansende og det sansede, er afstandsløsheden i sansningen en naturlig konsekvens. Men det er naturligvis endnu uforklaret, hvorledes dette kan give sig ud for at være en fænomenologisk beskrivelse. Man oplever sig jo ikke afstandsløst forenet med det sansede, når man sanser det. Men den indvending er foregrebet $i$ ovenstående fremstillings betoning af den abstrakte beskrivelse af sansningen. Man kan netop aldrig se bort fra, at man er en kropsligt konstitueret person, når man sanser. Og man kan ikke abstrahere fra, at det sansede er noget i sig selv. Det gør Løgstrup alligevel, og derfor er hans redegørelse spekulativ (Løgstrup 1984, 28). Hos ham hedder det, at forståelsen skaber afstanden mellem den sansende og det sansede, når den etablerer det sansede som et særskilt fænomen adskilt fra selve sansningen. Afstanden opstår, fordi det sansede forstås som noget andet end sansningen og altså noget andet end den sansende (Løgstrup 1984, 21). Når lyden forstås som køleskabets summen, når smerten forstås som varmen fra strygejernet, når lugten forstås som stanken fra marken, når lyset forstås som spejlets refleksion af solens stråler, når man forstår smagen som blod. Eksempelrækken viser, at det er umuligt at komme bag om forståelsen, for selv når man ikke ved, hvad man sanser, ved man, at man sanser noget, nemlig en lyd, en følelse, en lugt, et syn, en smag. Allerede den forståelse, som man ikke kan komme bagom, skaber afstanden.

Løgstrup finder, at sansningens afstandsløshed går tabt ved forståelsen, men sætter sig igennem på en anden måde. Den ændrer sig til allestedsnærværelse. Afstandsløsheden ophører, når sansningen bindes til en person og derfor også til en krop. Sansningen er begrænset af den person, som sanser. Imidlertid opfatter Løgstrup det forhold, at sansningen ikke i sig selv er begrænset som en reminiscens af afstandsløsheden. Der er ingen steder, man ikke kan sanse. Over alt, hvor sanseorganerne kan komme til, kan der sanses. På den måde viser sansningen sin principielle ubegrænsethed på trods af begrænsningen i kroppen. I legemet er personen et-steds-tilstedeværende, men i sansningen er han allestedsnærværende: "I min sansning er jeg ikke fængslet i mit legem, jeg er borte fra det. I min sansnings rum, langt borte fra mit legem, bevæger min opmærksomhed sig frit omkring" (Løgstrup 1984, 19).

Man kan sammenfatte denne korte fremstilling ved at påpege de to forskellige abstraktionsniveauer, som Løgstrup opererer på. Helt abstrakt og spekulativt beskrives sansningen som afstandsløs. Analysen 
fungerer kun under bortseen fra bevidsthed, forståelse og kropslighed og befinder sig derfor på det højeste abstraktionsniveau. Mindre abstrakt er redegørelsen, når sansningen betegnes allestedsnærværende, for på dette niveau er bevidstheden, forståelsen og kroppen inddraget. Allestedsnærværelsen opleves i modsætning til afstandsløsheden, fordi sansningen netop overskrider kroppens grænser og bringer den $\mathrm{i}$ kontakt med alle ting uden for den selv.

Afgørende for Løgstrups projekt er det, at denne forståelse af sansning bringer mennesket bort fra randtilværelsen i universet:

Mennesket befinder sig ikke på kanten af universet, for det er ved sansningen indfældet i det: Universets udslag og uindskrænkede regimente i vor sansning har vi ikke den bitterste mulighed for at reservere os overfor eller korrigere. I sansningen forføjer universet over den sansende, totalt (Løgstrup 1984, 15).

Sansningen er afmægtig overfor universet, der er umodificeret og ureduceret til stede i sansningen. Af den grund har mennesket ingen særstatus i universet. Det er indfældet i det.

Men når menneskets sansning er afmægtig, idet den er afstandsløst ét med det sansede og allestedsnærværende til stede hos det sansede, kan det sansedes sansekvaliteter ikke stamme fra mennesket. For Løgstrup fører det til en religiøs tydning. Når der er forskel mellem sansningen, den sansende og det sansede, kan sansekvaliteterne ikke stamme fra det sansede selv. Hvis noget har sansekvaliteter må det være sanset, ellers ophæves sansningens trehed mellem sansningen selv, det sansede og den sansede. Men da universets sansekvaliteter ikke kan tilskrives mennesket, fordi sansningen er afmægtig over for universet, må de komme fra en anden sansende:

Sansningen sætter en trehed, sig selv, det sansede og den sansende. Også for universets vedkommende. Lade universet beholde sansekvaliteterne og frakende det sansning er ugørligt. Sanset er universet sansende. Vil vi ikke vide af det, men frakender vi universet sansning, tager vi sansekvaliteterne på vor kappe. Enten kommer sansekvaliteterne fra os eller de tilkommer universet, og i sidste fald har universet den sansning, der skal til for det. Den kan ikke være andet end skabende (Løgstrup 1984, 27). ${ }^{8}$

8. En lignende metafysisk trehed sættes af tilintetgørelsen, væren og magten til at være til. K.E. Løgstrup, Skabelse og tilintetgørelse. Religionsfilosofiske betragtninger. Metafysik IV, København: Gyldendal 1978, 176. 
Således ender Løgstrups analyse af sansningen i en spekulativ religiøs tydning. Der må være en magt, der tilsanser universet sansekvaliteter, ellers kunne universet ikke være ubearbejdet til stede i den afstandsløse sansning.

\section{Fænomenologi eller ej}

Som allerede antydet er Løgstrups sansningsteori et kontroversielt punkt. Receptionen af den spænder da også fra mere eller mindre hovedrystende afvisning til en kreativ videreudvikling. I diskussionen har det været et hovedpunkt, om Løgstrups beskrivelse af sansningen overhovedet kan gælde som fænomenologisk.

På den ene side af spektret befinder Vagn Andersen sig. Med en formulering, der er rammende for megen kritik af Løgstrups opfattelse af sansningen, afviser han beskrivelsen som fænomenologisk:

Abstraherer jeg alt sprog, al forståelse og al historicitet væk fra min sansning, er jeg - måske - så at sige som en abstrakt teoretisk grænsestørrelse i stand til at forestille mig en sansning, sådan som Løgstrup beskriver den, men nogen oplevelsesmæssig adgang til den har jeg ikke.?

I stedet må Vagn Andersen opfatte begreberne "afstandsløshed" og "allestedsnærværelse" som diffuse metaforer.

Lige så kritisk er Peter Widmann, der påpeger, at fænomenologi traditionelt ikke beskæftiger sig at finde ind til et ureduceret fænomen uafhængigt af den menneskelige betydningsdannelse:

Snarere tværtimod. Det man i den fænomenologiske beskrivelse vil komme bort fra, er aldeles ikke den historieskabte betydningsverden, [sic!] for at få fat på universets tilkendegivelser selv. Det, man vil komme bort fra, er opslugtheden i den verden, vi forholder os til i den betydningsskabende aktivitet. Blikket skal vendes mod selve den betydningsskabende aktivitet, mod de bevidsthedsydelser, der lader verden være til som verden. ${ }^{10}$

9. Vagn Andersen, "Natur og historie. Problemer i K.E. Løgstrups fænomenologiske metafysik", i Per Dahl og Svend Andersen (red.), Universet $i$ historien, Aarhus: Forlaget Anis 1986. (1986), 86-98 (90).

10. Peter Widmann, "Metafysikeren Løgstrup. Om "Ophav og omgivelse" samt et tilbageblik på Metafysik I-IV”, RvT 1985:7, 65-90 (83). 
Af den grund mener Peter Widmann, at Løgstrup har forladt fænomenologiens problemområde i sit projekt med at finde universet selv i sansningen.

Mogens Pahuus er ligeledes kritisk over for Løgstrups analyse, men på et andet grundlag. Han anerkender en del af beskrivelsen af sansningen: "Der er altså en fænomenologisk kerne i bestemmelsen af den eksistentielt betydningsfulde sansning som afstandsløs." 11 Men dette indebærer ifølge Mogens Pahuus ikke, at rummet ophæves i sansningen. Det er fænomenologisk forkert, for rummet opleves i sansningen, selv om man i selvforglemmelse og henrykkelse ikke oplever afstande. Det er nemlig for Mogens Pahuus kun i sådanne ekstraordinære intense oplevelser, at sansningens afstandsløshed har et erfaringsmæssigt grundlag (Pahuus 1986, 74-76).

En af de væsentligste filosofiske læsninger af Løgstrup findes hos Hans-Jørgen Schanz, der stiller sig positivt over for ideen om sansningens afstandsløshed. Den mener han at kunne fastholde uden at overtage Løgstrups skabelsesfilosofi (Schanz 1990, 162). For Schanz er pointen, at Løgstrup med sin opfattelse af sansningen giver filosofien kropslighed (Schanz 1990, 159). Sansningen forbinder bevidstheden, erkendelsen og sproget med universet, derfor er Løgstrup interessant som slutpunkt i Schanz' redegørelse for afviklingen af modernitetens bevidsthedsfilosofi (Schanz 1990, 179). Uden at reflektere over dens metodiske grundlag accepterer Schanz Løgstrups beskrivelse af sansningen som afstandsløs. Tilsyneladende finder han ikke dens forandring til allestedsnærværelse relevant. ${ }^{12}$ For Schanz er det afgørende alene indfældetheden i universet.

Hans Hauges Løgstrup-læsning sammenfatter i en vis forstand to linier i kritikken af Løgstrups teori om sansningen. ${ }^{13}$ På den ene side følger han Vagn Andersen i, at Løgstrups beskrivelse af sansningen ikke er fænomenologisk i egentlig forstand. Der er ikke erfaringsmæssig adgang til sansningen som afstandsløs (Hauge 1992, 637f). På den anden side fortolker han teorien om sansningen som en æstetik og giver derved Mogens Pahuus ret i, at beskrivelsen angår særlige er-

11. Mogens Pahuus, "Sansning og forståelse. En transcendentalfilosofisk kritik af Løgstrups metafysik", i Per Dahl og Svend Andersen (red.), Universet i historien, Aarhus: Forlaget Anis 1986, 70-85 (74); jf. Mogens Pahuus, "K.E. Løgstrups eksistentielle fænomenologi", i Slagmark 2005:42, 117-127 (123-125).

12. På trods af at kroppen først optræder i Løgstrups analyse, når afstandsløsheden forvandles til allestedsnærværelse.

13. Hans Hauge, K.E. Løgstrup. En moderne profet, København: Spektrum 1992, 613-643. 
faringer (Hauge 1992, 615-618). ${ }^{14}$ De sublime oplevelser er den privilegerede tilgang til virkeligheden, for universet er æstetisk til stede i sansningen (Hauge 1992, 640). For Hauge er det imidlertid væsentligt at pointere, at denne umiddelbare adgang hindres i forståelsen. Ved forståelse skabes afstand, der fyldes op af sproget, der derfor ikke siger noget om det univers, som det lægger afstand til (Hauge 1992, 642). Sproget ender i Hauges tolkning med at blive løsrevet fra universet. Det refererer ikke til universet og kan derfor heller ikke påvirke det. Resultatet er derfor, at der går en sproglig mur ned mellem os og universet (Hauge 1992, 642). ${ }^{15}$

To introduktioner til Løgstrups tænkning kommenterer hans teori om sansningen kritisk. Både Nils Gunder Hansen og Niels Thomassen finder, at Løgstrups opfattelse er for abstrakt og uden oplevelsesmæssig baggrund. ${ }^{16}$ De har således svært ved at acceptere sansningens afstandsløshed, fordi sansningen er bundet af en konkret kropslighed. Af den grund finder Nils Gunder Hansen, at Løgstrup blot beskriver et bestemt fænomen ved sansningen, nemlig at man i sansningen kan vandre hid og did og fordybe, ja forglemme sig (Hansen 1998, 232). Niels Thomassen opfatter derimod afstandsløsheden som et mindre interessant grænsefænomen, fordi den ikke er knyttet til forståelse (Thomassen 1992, 48). ${ }^{17}$ Endvidere mener begge i modsætning til

14. Ang. forholdet mellem Løgstrups metafysik og æstetik, se bidragene i Per Dahl og Svend Andersen (1984).

15. Spørgsmålet er dog, om denne tolkning modsvarer Løgstrups opfattelse. Sproget er ifølge Løgstrup ikke løsrevet fra verden. Tværtimod er der en metafysisk korrespondance mellem sprog og virkelighed, der muliggør et samspil. K.E. Løgstrup, Vidde og pregnans. Sprogfilosofiske betragtninger. Metafysik I, København: Gyldendal 1976, 142. Sprogets tydning er udtryk for en analog forståelse af den virkelighed, som det tyder. "Universets analoge orden kommer til orde i sproget, og det er ikke sproget, der bringer orden til veje i et univers, der skulle være i uorden." Løgstrup (1984), 136; jf. Løgstrup (1978), 135f; jf. Ole Jensen, "Løgstrup som senmoderne tænker. Hans Hauges disputats", i Ole Jensen, Sårbar usårlighed. Løgstrup og religionens genkomst i filosofien, København: Gyldendal 1994, 199-230 (221-228).

16. Niels Thomassen, Filosofisk impressionisme. Temaer i K.E. Løgstrups filosofi, København: Gyldendal 1992, 37; Nils Gunder Hansen, En afgrund af tillid. Guide til Løgstrups univers, København: Gyldendal 1998, $232 \mathrm{f}$.

17. Om Thomassens korrektiv har vægt i forhold til Løgstrups anliggende er tvivlsomt. For Løgstrup er det netop vigtigt at abstrahere den sansende bevidsthed fra sansningen for at kunne hævde, at sansningen er indlejret $\mathrm{i}$ universet, mens forståelsen er afstandsskabende. Det rammer ik- 
Løgstrup, at denne form for sansning altid vil være forbundet med en bevidsthed (Hansen 1998, 233; Thomassen 1992, 43f). ${ }^{18}$

At Løgstrups beskrivelse af sansningen er fænomenologisk, forsvares derimod flere steder af Ole Jensen. ${ }^{19}$ I sin introduktion til Løgstrups forfatterskab godtager han Løgstrups opfattelse og tilføjer endvidere korrigerende, at den rene sansning slet ikke er en spekulation. I sjældne situationer erfares sansning uden forståelse, fx når man vågner med en lyd i øret uden at have erkendt, hvor lyden kommer fra. ${ }^{20}$

Den mest vidtgående Løgstrup-fortolker er Jakob Wolf. ${ }^{21}$ Han insisterer på, at Løgstrups fremstilling af sansningen er i overensstemmelse med erfaringen. Selv om Løgstrup kalder både sansningen (Løgstrup 1984, 19) og sin redegørelse (Løgstrup 1984, 28) spekulativ, er det ikke tilfældet ifølge Jakob Wolf: "Men afstandsløshed er ikke et spekulativt begreb. Det er rigtigt, at det ikke er et "empiri-

ke Løgstrups opfattelse at sige, at "vi er dybt afhængige af det sansede, herunder også universet. I den forstand er det ophav..." (Thomassen 1992, 48). For Løgstrup er pointen, at mennesket i den rene sansning er uadskilt fra universet. Adskillelsen indtræder først med forståelsen.

18. For mig at se overser kritikken, at Løgstrups redegørelse er spekulativ og abstrakt. Det er netop ikke den sansende, der er afstandsløs og allestedsnærværende, men derimod sansningen, som ikke er knyttet til en bevidsthed, førend forstålsen kommer til og skaber den afstand, som sproget fylder ud. Imidlertid er enhver konkret sansning forbundet med forståelse, hvorfor man aldrig oplever den rene sansnings afstandsløshed. Allestedsnærværelsen erfares derimod ifølge Løgstrup, fordi sansningen kan være alle steder. Det er blevet indvendt, at dette kun gælder 'fjernsanserne', hørelsen og navnlig synet, mens 'nærsanserne', lugte-, smage- og følesansen, er rumligt begrænsede (Hansen 1998, 237; Thomassen 1992, 38). Men forskellen er næppe så stor. Synet er allestedsnærværende, fordi alt inden for synsfeltet kan ses. På samme måde er følesansen allestedsnærværende, fordi alt inden for rækkevidde kan føles. Det ændrer ikke ved, at sansningen principielt kan sanse alle steder. Helt med rette påpeger Jakob Wolf, at begrænsningen omhandler betingelserne for sansningen, ikke sansningen selv. Jakob Wolf, "Sansning og æstetik", i Per Dahl og Svend Andersen (1984), 31-42 (33); Wolf (1990), 208

19. Se også Svend Andersen, "Erfaringsbeskrivelse. Løgstrup og fænomenologien”, i David Bugge, Pia Rose Böwadt og Peter Aaboe Sørensen, Løgstrups mange ansigter, København: Forlaget Anis 2005, 13-25 (22-24).

20. Ole Jensen, Historien om K.E. Løgstrup, København: Anis 2007, 138.

21. Om sansningen se Wolf (1984), 31-42; (1990), 208-213; (2005); Jakob Wolf, Etikken \& universet, København: Forlaget Anis 1997; jf. Jakob Wolf, "Teori og sansning," i V. Mortensen (red.), Gud og naturen. Kan der etableres en dialog mellem teologi og naturvidenskab, Munksgaard 1990, 32-36. 
stisk” begreb. Det er et fænomenologisk begreb” (Wolf 1990, 210). Samtidig overfører han opfattelsen til Løgstrups religiøse tydning. For Wolf ligger opfattelsen af universet som skabt i direkte forlængelse af den umiddelbare fænomenologiske tilgang til verden. Tydningen melder sig spontant og skabes således i sidste ende af universets egen værensmagt. ${ }^{22}$

Løgstrups fortolkeres åbenlyse uenighed angående analysen af sansningen angår i særlig grad dens status som fænomenologi. På den ene side afviser flere fortolkere at kunne eftergøre den sansning, som Løgstrup mener at beskrive fænomenologisk. På den anden side viderefører andre fortolkere beskrivelsen og hævder, at den endog er mere erfaringsnær, end Løgstrup selv antog. Den følgende sammenligning mellem Løgstrups sanseteori og Peirces phaneroscopy vil indgå i denne diskussion. Påstanden vil være, at Løgstrup faktisk beskriver et aspekt af sansningens fænomen, men at dette fænomen er langt mere komplekst, end det fremstår i Løgstrups analyse. Af den grund kan hans teori isoleret set vanskeligt overbevise som fænomenologi, men kan accepteres som en del af en større fænomenologisk redegørelse for sansningen. Med den påstand lægges der afstand til begge sider af Løgstrup-læsningerne.

\section{Charles Sanders Peirce}

Kronologisk hører Charles Sanders Peirce (1839-1914) til blandt gruppen af amerikanske filosoffer fra slutningen af det 19. årh. Han var uddannet kemiker og virkede lang tid ved 'The US Coast Survey', men fik aldrig fast universitetsansættelse. Han tilhørte den såkaldte 'Metaphysical Club' omkring Harvard University sammen med blandt andre filosofferne William James, Josiah Royce og John Dewey. Livet igennem stod Peirce i forbindelse med denne gruppe af pragmatismens fædre. I modsætning til disse havde han dog meget begrænset gennemslagskraft i sin samtid og først i sidste halvdel af det 20. årh. begyndte den stadigt mere omfattende reception af hans værker. Det er ikke uden grund, at han kaldes det 21. årh.'s filosof. ${ }^{23}$

De biografiske forhold giver en indledende forestilling om karakteren af Peirces tænkning. Den omfatter et usædvanligt stort tematisk

22. Jakob Wolf, Den skjulte Gud. Om naturlig teologi, København: Forlaget Anis 2001, 181-189.

23. Fra den omfattende litteratur om Peirces liv og værk skal blot Max Fischs fremragende bidrag nævnes: Max H. Fisch, Peirce, Semeiotic and Pragmatism, Bloomington: Indiana University Press 1986. 
spektrum fra bl.a. kosmologi, matematik og logik over fysik, biologi og astronomi til filosofi, semiotik og fænomenologi. Mellem de vidt forskellige emneområder er der flere forskellige forbindelseslinier og strukturelle sammenhænge. Enhver læser vil på grund af vidden i Peirces forfatterskab sikkert finde skrifter, der på grund af deres tema forekommer fremmedartede og uigennemtrængelige, men på grund af gennemgående modeller og tankefigurer har de alle et særegent præg. Et af de markante og karakteristiske træk ved Peirces tænkning er tredelinger og triader, som går igen på alle niveauer $\mathrm{i}$ hans analyser og undersøgelser.

Også bibliografisk antyder Peirces livshistorie hans værks beskaffenhed. I sin levetid publicerede Peirce relativt begrænset. Han har ikke udgivet en monografisk filosofisk eller semiotisk fremstilling eller for den sags skyld en samlet redegørelse for nogen af de andre emner, som han beskæftigede sig med. Hans offentliggjorte forfatterskab består hovedsageligt af tidsskriftartikler og publicerede forelæsninger, men nok så vigtigt er en mængde upublicerede og i mange tilfælde ufuldstændige manuskripter og breve, som er inkluderet i standardudgaven af hans værker. ${ }^{24}$

Forfatterskabet er på mange måder utilnærmeligt. De nævnte forhold medfører den vanskelighed, at de overleverede skrifter bevidner forskellige udviklingstrin i hans tænkning. Man kan ikke forudsætte, at der findes én opfattelse eller tolkning af hvert tema eller problem i hans skrifter. Tværtimod kan man i visse tilfælde tydeligt efterspore en udvikling, hvilket indebærer, at man ikke nødvendigvis kan sammenfatte hans opfattelse i én systematisk fremstilling. Det gælder i særlig grad den semiotiske del af hans forfatterskab, mens den fænomenologiske synes at have større sammenhæng.

Endelig er det en vanskelighed ved tilegnelsen af Peirces tanker, at han som nævnt befinder sig i en filosofisk diskussion i slutningen af det 19. årh. og delvist beskæftiger sig med forhold, som hans samtidige også arbejder med. Samtidig tager han dog eksplicit afstand ikke bare fra deres opfattelser, men også fra deres tilgang til de pågældende emner. Af den grund anvender Peirce en række neologismer for at adskille sin egen position fra sine samtidiges. Således kalder han sin

24. C. Hartshorne og P. Weiss (red.), Collected Papers of Charles Sanders Peirce I-VIII, Cambridge: Harvard University Press 1931-1958 (forkortes CP). En bedre kronologisk udgave af de væsentligste skrifter i deres fulde længde er imidlertid The Peirce Edition Project (red.), The Essential Peirce. Selected Philosophical Writings I-II, Bloomington: Indiana University Press 1992-1998 (forkortes EP). 
semiotik semeiotic, sin pragmatisme pragmaticisme og sin fænomenologi phaneroscopy.

Formålet her er ikke at introducere Peirces tænkning, men at bidrage til Løgstrup-fortolkningen, derfor skal alene Peirces fænomenologiske bidrag præsenteres.

\section{Peirces phaneroscopy}

Intet tyder på, at Løgstrup har kendt Peirce på første hånd. Ingen bøger af eller om Peirce findes i Løgstrups efterladte bogsamling, og en søgning i Løgstrup-arkivets database giver blot et enkelt resultat: I et håndskrevet forarbejde til kapitlet "Jacques Derridas sprogfilosofi" i Vidde og pragnans (Løgstrup 1976, 153-171) er der nogle bemærkninger om Peirce. ${ }^{25}$ Men de er alle foranlediget af Jacques Derridas gengivelse og tolkning af Peirce i De la grammatologie, som Løgstrup gennemgår i notatet. Alligevel vil det vise sig værdifuldt at sammenligne Løgstrups fænomenologiske og spekulative teori om sansningen med Peirces fænomenologiske kategorilære.

Peirces fænomenologiske analyser er et ambitiøst projekt. ${ }^{26}$ Det gælder intet mindre end at erstatte Aristoteles' og Kants kategorilære med en enklere og mere grundlæggende inddeling. Han trækker i den forbindelse på Hegel (jf. EP 2:148f; CP 5.43), men det afgørende er hans egne betragtninger over altings beskaffenhed. I modsætning til Kant opfatter han nemlig ikke kategorierne som grundlæggende skemaer for erkendelse af virkeligheden. I Peirces fænomenologiske kategorilære hidrører kategorierne fra fænomenet selv.

Det er interessant at se, hvilke evner fænomenologen ifølge Peirce må være i besiddelse af. For det første må han have en udviklet observationsevne. Han skal kunne se alle fænomenets bestanddele og detaljer:

Be it understood, then, that what we have to do, as students of phenomenology, is simply to open our mental eyes and look well at the phenomenon and say what are the characteristics that are never wanting in it, whether that phenomenon be something that out-

25. Manuskriptet er katalogiseret som Fasc. II.24.

26. Som nævnt findes Peirces fremstillinger altid i mange forskellige tekster. For den følgende redegørelse lægges fortrinsvis forelæsningen "On Phenomenology” holdt på Harvard University i 1903 (EP 2:145-159; jf. CP 5.41-56.59-65) og afsnit af manuskriptet "A Guess at the Riddle" fra 1887-88 (EP 1:245-279; jf. CP 1.354.355-368.373.374-375.379383.385-416) til grund. 
ward experience forces upon our attention, or whether it be the wildest of dreams, or whether it be the most abstract and general of the conclusions of science (EP 2:147; CP 5.41).

På dette niveau svarer det fænomenologiske arbejde til kunstnerens iagttagelse og indlevelse. Fænomenologens mest efterspurgte evne er

...the faculty of seeing what stares one in the face, just as it presents itself, unreplaced by any interpretation, unsophisticated by any allowance for this or that supposed modifying circumstance. This is the faculty of the artist ... (EP 2:147; CP 5.42).

Både kunstneren og fænomenologen ser fænomenet, som de umiddelbart forekommer. ${ }^{27}$ Imidlertid må fænomenologen også være udstyret med en evne til at sondre, så han kan fastholde analysen af et objekt under udelukkelse af alle andre. Fænomenologen må altså erhverve sig "a resolute discrimination which fastens itself like a bulldog upon the particular feature that we are studying, follows it wherever it may lurk, and detects it beneath all its disguises" (EP 2:147; CP 5.42).

Endelig er den fænomenologiske analyse afhængig af en abstraktionsevne, som svarer til en matematikers. Han må trænge ind til kernen i ethvert fænomen uden alle irrelevante følgeelementer. På det grundlag kan fænomenerne kategoriseres. Den tredje evne er "the generalizing power of the mathematician who produces the abstract formula that comprehends the very essence of the feature under examination" (EP 2:147f; CP 5.42).

Udrustet med disse tre evner foretager Peirce sine fænomenologiske analyser. Det er væsentligt at bemærke, at hele undersøgelsen adskiller sig væsentligt fra den kontinentale fænomenologiske tradition og ikke mindst fra Løgstrups fænomenologiske fremgangsmåde. Peirce undersøger ikke enkeltfænomener med henblik på en klargørelse af

27. Også hos Løgstrup har kunstnerens udtryk en privilegeret status. Jf. hans fremstilling af kunstnerens forhold til sansningen: "Kunstneren er ikke til sinds at lade den fortrolighed med universet, som dets nærvær i sansningen byder på, lade sig gå forbi. Da nu universet er enevældigt til stede i sansningen og det sansende menneske intet har at skulle have sagt, kan det ikke lade sig gøre på anden måde end at foregive at lade universet selv komme til orde" (Løgstrup 1984, 75).

Ifølge Løgstrup lader kunstneren gennem symbolet universet komme til orde i kunstværket (Løgstrup 1984, 78), jf. K.E. Løgstrup, Kunst og erkendelse. Kunstfilosofiske betragtninger. Metafysik II, København: Gyldendal 1983, 9-17. 
deres beskaffenhed. Hans mål er at erkende de træk, der er grundlæggende i den menneskelige omgang med virkeligheden. På den måde er hans fænomenologi langt mere abstrakt og spekulativ, da han ikke interesserer sig for konkrete fænomener, men deres generelle og fælles træk. Peirce ender med tre forskellige kategorier, der hver især udtrykker forskellige aspekter af virkelighedens fænomener. Man finder aldrig aspekterne $\mathrm{i}$ ren form, da ethvert fænomen indeholder alle aspekter, men ved nogle fænomener er et aspekt mere fremtrædende end andre. Peirce kalder sine tre kategorier Førstehed, Andethed og Tredjehed.

Førsteheden er en monadisk kategori. Den forudsætter ikke noget andet eller tredje, mens den tværtimod bliver forudsat af Andet- og Tredjeheden. Den har derfor ikke eksistens, da eksistens er en dyadisk kategori, hvor noget får væren. Heri er der altså to aspekter involveret, mens Førsteheden blot er et enkelt. Fra Førsteheden kan der derfor ikke abstraheres yderligere. Den er det tilbageblevne, når alt andet ignoreres, således er den fænomenologiens første kategori. Af samme grund er den ren potentialitet og kvalitet, for den består af en følelse, der vil kunne fă eksistens. Kvaliteten er det sanseindtryk, følelse eller fornemmelse, som ethvert fænomen i større eller mindre grad medbringer. Ved visse fænomener er kvaliteten det fremtrædende aspekt, fx smerte eller musik. Mens det ved andre kan være yderst tilbagetrukket, $\mathrm{fx}$ abstrakte teorier eller matematiske beviser. Ikke desto mindre er kvaliteten altid tilstedeværende ved alle fænomener.

Førsteheden i dens rene form er naturligvis en abstraktion, men det er i denne sammenhæng væsentligt at se Peirces fremstilling af dette abstrakte fænomen. Han illustrerer det således:

Imagine, if you please, a consciousness in which there is no comparison, no relation, no recognized multiplicity (since parts would be other than the whole), no change, no imagination of any modification of what is positively there, no reflexion, - nothing but a simple positive character. Such a consciousness might just be an odor, say a smell of attar; or it might be one infinite dead ache; it might be the hearing of [a] piercing eternal whistle. In short, any simple and positive quality of feeling would be something which our description fits, - that is such as it is regardless of anything else (EP 2:150; CP 5.44).

Førstehedens monadiske karakter betyder, at den må være uden forandring, uden relationer, uden brud, uden forskelle, uden dele og uden afstand. Dens kvalitet er præsentisk og identisk med sig selv, 
derfor kan den ikke indeholde afstand eller være begrænset af andre forskelsskabende relationer. Førsteheden er ét.

Andetheden er en dyadisk kategori. Den forudsætter et første, men ikke et tredje. Den er eksistens, idet Andetheden giver Førstehedens potentialiet væren. Derfor er Andetheden altid forbundet med et første, som den aktualiserer. Man kan sige, at Andethedens eksistens sætter Førstehedens kvalitet i verden. Uden Andethed er Førsteheden ren mulighed, men gennem Andethed, der er fænomenernes konkrete faktuelle eksistens, gives den aktualitet. Andetheden er således fænomenernes identitet som fakta. Af den grund anvender Peirce kampen eller modstanden ('struggle') som beskrivelse af Andethed (EP 2:150f; CP 5.45f). Kampen defineres som en gensidig vekselvirkning mellem to ting uden hensyn til noget tredje (CP 1.322f). I kampens modstand opleves det andets konkrete identitet. Således bliver fænomenet det andet i kraft af den modstand, som det yder i opfattelsen af det. Alle fænomener indeholder dette aspekt, for så vidt de er eksisterende, thi deres kvalitet må være forbundet med ét forhold, der står i modsætning til andre forhold. Således opleves sansekvaliteter som hårdhed, farve, smerte etc. først, når de er forbundet med noget andet. Hårdheden findes, når muren yder modstand mod et pres. Farven opleves i kraft af den flade, som det er bundet til. Smerten opstår, når noget påvirker kroppen. Om end eksemplerne ikke er entydige, turde pointen være klar. Andetheden yder modstand, og derfor giver den Førsteheden en konkret eksistens, som er adskilt fra andre konkrete eksistenser. Andetheden er fænomenernes karakter af 'hard facts':

We find secondness in occurrence, because an occurrence is something whose existence consists in our knocking up against it. A hard fact is of the same sort; that is to say, it is something which is there, and which I cannot think away, but am forced to acknowledge as an object of second beside myself, the subject or number one, and which forms material for the exercise of my will (EP 1:249; CP 1.358).

Andethedens dyadiske karakter betyder, at den implicerer forskel, forhold og deling. Den forholder sig netop til det første, som den forudsætter og er forskellig fra. Således kan man sige, at Andethedens aspekt er afstandsskabende, idet det konstituerer fænomenet som noget selvstændigt eksisterende adskilt fra noget andet. Ligeledes ændres Førstehedens potentialitet til aktualitet, hvilket imidlertid også medfører, at den bindes til et fænomen uden for den menneskelige bevidsthed. Det er ikke tilfældet for den rene Førstehed, der findes som 
en mulighed i den menneskelige forestillingsevne og derfor var ren mulighed. Når denne mulighed får eksistens ved noget andet, etableredes den som et faktum, hvis eksistens ikke er afhængig af nogens bevidsthed.

Tredjeheden er en triadisk kategori. Den forudsætter såvel det første som det andet, fordi den betegner relationen mellem dem. Tredjehed er den sammenhæng, lov, lovmæssighed eller vane, der forbinder Førstehed og Andethed. Også dette aspekt findes i alle fænomener, idet enhver forbindelse mellem det første og det andet konstitueres af noget tredje. Tredjeheden kan være den afstand, der forbinder udgangspunktet og endemålet; den kan være gavegivningen, når $\mathrm{A}$ giver B til C; eller den kan være den kemiske proces, der forbinder malingen med væggen. Sagen er, at alle fænomener er triader, idet de består af tre uløseligt forbundne elementer:

First and Second, Agent and Patient, Yes and No, are categories which enable us roughly to describe the facts of experience, and they satisfy the mind for a long time. But at last they are found inadequate, and the Third is the conception which is then called for. The Third is that which bridges over the chasm between the absolute first and last, and brings them into relationship (EP 1:249; CP $1.359)$.

Uden Tredjeheden ville forbindelsen mellem de to forudsatte dele ikke opstå, derfor er Tredjehed pr. definition en relationel kategori. Men den er mere end det. Tredjeheden er tillige den kategori, der betegner fænomenernes intelligibilitet. Hverken Førstehedens kvalitet eller Andethedens faktum har mening. Det er nemlig kun i og med det tredje element, at fænomenet kan antage betydning.

Not only meaning always, more or less, in the long run, mould reactions to itself, but it is only in doing so that its own being consists. For this reason I call this element of the phenomenon or object of thought the element of Thirdness (CP 1.343).

Det forhold, at det kun er i kraft af noget tredje, at mening opstår, udfoldes udførligt i Peirces semiotik (jf. fx EP 2:267-288, CP 2.274331). I denne forbindelse er det tilstrækkeligt at konstatere, at Tredjeheden medfører forståelse. Mødet med fænomener som hårde fakta indeholder ingen erkendelse af deres betydning, denne opstår først, når de afføder en særlig reaktion. Uden nogen relation mellem Førsteheden og Andetheden kunne dette ikke opstå. Eksempelvis indebærer hverken hårdheden eller betonmuren i sig selv en forståelse. 
Forståelsen kommer ikke før forbindelsen mellem disse to aspekter er draget og omsat til erkendelsen af den lovmæssighed, at betonmure er hårde, hvilket resulterer $\mathrm{i}$, at man går uden om dem. Først i erkendelse af lovmæssigheden mellem Førstehed og Andethed kan der afsættes en vane, som kan kaldes forståelse af fænomenets betydning. Mening er nemlig ifølge Peirce lig med de vaner, som et fænomen afføder (EP 2:418; CP 5.491). Tredjeheden er altså det fænomenologiske aspekt, som er betingelsen for forstålse, for Tredjeheden er relation mellem Førstehed og Andethed og skaber i forstålsen relation mellem betragteren og fænomenet.

Man kan sammenfatte således, at fænomener af Peirce anses for at indeholde tre inhærente aspekter. Førsteheden er dets kvalitet, Andetheden dets eksistens og Tredjeheden dets relation. Alle tre aspekter findes i alle fænomener, men det kræver forskellige intellektuelle operationer at blive opmærksom på dem.

\section{Sansningens phaneroscopy}

Løgstrup og Peirce adskiller sig i mangt og meget fra hinanden, men de refererede analyser har i hvert fald ét fællestræk: De er begge abstrakte og spekulative. Løgstrup må bortabstrahere forståelsen for at nå til den rene sansning; Peirce abstraherer fra to aspekter ved fænomenerne for at definere det tredje. Hverken den rene sansning eller Førsteheden, Andetheden eller Tredjeheden findes solo. Sansningen er altid ledsaget af forståelse, og alle tre aspekter er altid til stede i forbindelse med alle fænomener. Fortolkes Løgstrups sanseteori på grundlag af Peirces phaneroscopy, bliver det muligt at forstå den som en del af en egentlig fænomenologisk bestræbelse. Løgstrups observationer er faktisk fænomenologiske, for så vidt de svarer til dele af Peirces redegørelse for fænomeners bestanddele. Men det bliver også klart, at de kun er dele af en fænomenologisk undersøgelse, der i større fuldkommenhed er fremlagt af Peirce.

Løgstrups beskrivelse af sansningen som afstandsløs, fordi den er ét med det sansede, før det forstås som sansning af noget, svarer til Peirce's beskrivelse af Førsteheden som ren kvalitet. Førsteheden er i sig selv ikke en kvalitet ved noget. Den er den rene følelse, som i dens abstrakte form ikke er bundet til noget. Af den grund indeholder Førsteheden i sig selv ingen erkendelse og ikke forbundet med afstand. Kunne man erfare den rene Førstehed, ville man ikke få noget at vide om noget, men være ren sanseoplevelse. Sansning af Førstehed ville være et kollaps af den sansende og det sansede. Bevidstheden ville være ét med den pågældende følelse. Dette svarer til Løg- 
strups beskrivelse: "I sansningen, står det alene til den, er der ingen afstand mellem den sansende og det sansede" (Løgstrup 1984, 42). Heraf følger, at den rene sansning er uden erkendelse: "Strengt taget viser sig intet i sansningen” (Løgstrup 1984, 28). Imidlertid er det ikke muligt at opleve den rene Førstehed, ligesom det ikke er muligt at erfare sansningens afstandsløshed. Men der findes fænomener, hvor Førsteheden er fremtrædende, ja dominerende. Det drejer sig primært om stærke sanseindtryk, fx en stærk gennemtrængende stank eller en uophørlig hyletone. ${ }^{28}$ Med sin beskrivelse af sansningens afstandsløshed har Løgstrup indfanget det aspekt ved fænomenerne, som Peirce definerer som Førstehed.

Først med Andetheden får kvaliteten eksistens og bliver en kvalitet ved noget. Derved bliver det placeret i rummet og bliver tilsvarende forlenet med afstand. Andetheden aktualiserer Førstehedens potentialitet, så Førsteheden bliver en kvalitet ved noget andet. Erfaringen af Førsteheden vil derfor være en erkendelse af noget. Med Førstehedens eksistens i kraft af Andetheden etableres det sansede som noget selvstændigt, der ikke er identisk med den sansende, men kan opleves i sin egen identitet. Hermed er afstandsløsheden forsvundet, men i stedet er allestedsnærværelsen opstået. Selve sansbarheden er allestedsnærværende, fordi det er aktualiseringen af Førsteheden gennem Andetheden. Dette er ikke, hvad Løgstrup mener, når han taler om sansningens allestedsnærværelse (Løgstrup 1984, 42f), for Andetheden er et aspekt ved fænomenet og ikke ved sansningen. Ikke desto mindre underbygger denne forståelse af forholdet mellem Førstehed og Andethed Løgstrups påstand om, at det er fænomenet selv, der melder sig i sansningen. I kraft af Førsteheden tillægges sansekvaliteten netop fænomenet selv, der har eksistens i kraft af sin Andethed. Endvidere er det dette aspekt, der er grundlag for, at sansningen kan opleves som allestedsnærværende. For sammenhængen mellem Førstehed og Andethed er grundlaget for, at alting kan erfares gennem sansning. Men lige så umuligt det er at erfare den rene Førstehed, ligeså umuligt er det at opleve den rene Andethed. Det ville være en eksistens uden kvalitet, hvorfor der ikke ville være noget at opleve. Imidlertid er det også umuligt at sanse Andetheden i kombination med Førsteheden. Det ville svare til, at den sansende stod over for det sansede uden at have sansningens relation mellem dem. Denne relation opstår først med Tredjeheden.

28. Ole Jensens eksempel på oplevet afstandsløshed i sansningen er unægtelig anderledes end dette, men det er ligeledes et fænomen med dominerende Førstehed (fuglesang) kombineret med en svækket bevidsthed (vågnende af søvn). Jensen (2007), 138. 
Når Tredjeheden kommer til forbindes Førsteheden og Andetheden, hvilket gør dem mulige at erfare som selvstændige fænomener med både eksistens og kvalitet. Den relation, som forbinder fænomenets aspekter, kan fx være forståelse. Når en kvalitet forstås som tilhørende en eksistens, er forudsætningen etableret for at sanse dette som et konkret fænomen. Af den grund opstår egentlig sansning af noget som noget bestemt først, når forståelsen kommer til. Til gengæld kan alt nu sanses som noget. Det er dette Løgstrup antyder: "En gang forstået er det så godt som umuligt at løse det sansede ud fra dets forståelighed” (Løgstrup 1984, 42). I Peirces optik skulle dette udsagn præciseres. Forståelsen er nemlig en del af sansningens helhed. Det er ikke muligt at sanse noget, før forståelsen selv er blevet et tredje, der forbinder Førsteheden og Andetheden. Også dette synes Løgstrup at have sans for: "Eet er altså, hvad der ligger i sansningen, noget andet er hvad der kan stå frem for sansningen" (Løgstrup 1984, 42). I sansningen ligger Førsteheden og Andetheden, men det kan først stå frem, når de er forbundet i forståelsen. Først da fremstår det sansede som noget sansbart for den sansende. Forståelse er således Tredjeheden, der relaterer Førstehed og Andethed og dermed konstituerer sansningens fænomen. Dermed er Tredjeheden årsag til sansningens allestedsnærværende. Når sansningen kan være alle steder, er det netop, fordi forståelsen leverer den relation, der gør det sansbare sansbart i sansningen. Sansningen er altså ude ved fænomenet, hvor forståelsens Tredjehed forbinder Førstehedens kvalitet og Andetheds eksistens.

Sammenligningen mellem Løgstrup og Peirce kan afslutningsvis illustreres med en fortolkning af et af Løgstrups kendte eksempler på sansningens allestedsnærværelse:

I mit syn er jeg ovre ved skovbrynet, der er $200 \mathrm{~m}$. borte, ikke fra mit syn, men fra min krop. I min hørelse er jeg oppe ved flyvemaskinen, der er $1000 \mathrm{~m}$. oppe, ikke over min hørelse, men over min krop. Var det ikke fordi vi er et legem, der kan bevæge sig imellem andre legemer, og var det ikke fordi vi lever et historisk liv i forståelse, ville det ikke være os, der havde det sansede, men det ville være det sansede, der havde os (Løgstrup 1978, 111).

Ud fra Peirces kategorier er synet af skovbrynet et fænomen, der består af et første, nemlig skovbrynets udseende, og et andet, nemlig skovbrynet selv, der er forbundet af et tredje, nemlig forståelsen, der forbinder skovbrynet og dets sansekvalitet. Fænomenet består af alle tre aspekter, derfor kan skovbrynets eksistens, dets kvalitet og forståelsen af deres sammenhæng ikke være hvert sit sted. Synet er ude ved 
skovbrynet, fordi det består af Førstehed, Andethed og Tredjehed, dvs. sansekvalitet, eksistens og forståelse, der sætter dem i forbindelse. Ligeledes med hørelsen. Den består af såvel forståelsen, der forbinder flyvemaskinen og lyden, som selve flyvemaskinen og lyden, dvs. forståelsens Tredjehed, flyvemaskinens Andethed og lydens Førstehed. Alle tre dele udgør hørelsens fænomen. Af den grund er hørelsen oppe ved flyvemaskinen, hvor forståelsen forbinder lyd og flyvemaskine. Det sansede består af Førstehed, Andethed og Tredjehed, derfor er sansningen ikke løsrevet fra det sansede, selv om den sansende i kraft af sit legeme befinder sig på afstand af det sansede.

Pointen med denne sammenligning er, at Løgstrups opfattelse af sansningen vinder i præcision gennem Peirces phaneroscopy, og som sådan er den en fænomenologisk beskrivelse af sansningen. For sansningens fænomen indeholder for det første en Førstehed, nemlig den kvalitet, der sanses og er årsag til den abstrakte afstandsløshed. For det andet indeholder den en Andethed, som er den eksistens, som Førsteheden er tilknyttet, hvilket er grundlaget for, at sansningen kan være alle steder, idet sansekvaliteten derved forbindes til et sted. Endelig for det tredje er forståelsen den Tredjehed, der forbinder Førstehed og Andethed, og netop i denne forbindelse findes sansningen.

\section{Perspektiver for den religiøse tydning af sansningens fænomen}

Ovenstående fortolkning har skullet opnå et dobbelt formål. Det var meningen at sætte Løgstrups teori om sansningen ind i en større fænomenologisk sammenhæng og dermed vise, at hans spekulative betragtninger over sansningens fænomen faktisk kan fungere som fænomenologiske beskrivelser. Samtidig skulle Peirces ekstremt abstrakte redegørelse suppleres med mere håndgribelig eksempler, der understøtter teoriens fænomenologiske anliggende. Løgstrups redegørelser blev derfor læst ind i og udlagt på baggrund af Peirces langt mere komplicerede og omfattende teori. Resultatet er, at Løgstrups betragtninger opfattes som beskrivelser af dele af Peirces generelle fænomenologi.

Hermed er der også åbnet for en teoretisk fundering af Løgstrups hovedanliggende. Løgstrup vil vise, at universet selv melder sig i sansningen, hvorfor universet ikke blot er omgivelse, men tillige ophav. Dette synspunkt kan nu begrundes $i$, at sansningen indeholder tre aspekter, hvoraf det første er universets afstandsløse nærvær, det andet den allestedsnærværende aktualisering af universet i konkrete eksistenser og endelig det tredje den forbindende forståelse. I kraft af Førsteheden melder universet sig i sansningen og ville fylde bevidst- 
heden, havde det ikke været for Andetheden og Tredjeheden. Det er det, Løgstrup havde brug for at vise.

Tilbage står spøgsmålet, hvilken betydning denne læsning af Løgstrup har for hans spekulative religiøse tydning af sansningens fænomen. Et udtømmende svar vil selvsagt kræve en selvstændig undersøgelse. Her skal det blot afslutningsvis antydes, at netop på dette punkt kan Løgstrup måske bidrage til udlægningen af en af Peirces mest gådefulde tekster. I artiklen "A Neglected Argument for the Reality of God" (EP 2:434-450; CP 6.452-491) redegør Peirce for sin opfattelse, at gennem en bestemt form for intellektuel aktivitet ('musement') vil ideen om Guds realitet ('reality') uvægerligt opstå. Udgangspunktet er Peirces phaneroscopiske redegørelse for de tre fundamentale kategorier, som i denne sammenhæng kaldes tre 'Universes of Experience' (EP 2:435; CP 6.455). En første adgang til disse er 'Pure Play', som leder videre til 'Musement', der udvikler sig til 'the Neglected Argument':

Now, Play, we all know, is a lively exercise of one's powers. Pure Play has no rules, except this very law of liberty. It bloweth where it listeth. It has no purpose, unless recreation. The particular occupation I mean - a petite bouchée with the Universes, - may take either the form of esthetic contemplation, or that of distant castle-building (whether in Spain or within one's own moral training), or that of considering some wonder in one of the Universes or some connection between to of the three, with speculation concerning its cause. It is this last kind, - I will call it "Musement" on the whole, - that I particularly recommend, because it in time flower into the N.A. [Neglected Argument] (EP 2:436; CP 6.458).

Denne proces beskrives også således:

It begins passively enough with drinking in the impression of some nook in one of the three Universes. But impression soon passes into attentive observation, observation into musing, musing into a lively give-and-take of communion between self and self. If one's observations and reflections are allowed to specialize themselves too much, the Play will be converted into scientific study; and that cannot be pursued in odd half-hours (EP 2:436; CP 6.459).

Men pointen er, at den videnskabelige undersøgelse af det pågældende fænomen kun er én reaktion, hvor hypotesen om Guds realitet er en anden: 
This is a specimen of certain lines of reflection which will inevitably suggest the hypothesis of God's Reality. It is not that such phenomena might not be capable of being accounted for, in one sense, by the action of chance with the smallest conceivable dose of a higher element, for if by God be meant the Ens necessarium, that very hypothesis requires that such should be the case. But the point is that that sort of explanation leaves a mental explanation just as needful as before (EP 2:439; CP 6.465).

Man kan udlægge det således, at hypotesen om Gud er den fænomenologiske forklaring udsprunget af fordybelsen i de tre universer og deres sammenhæng. For så vidt synes Løgstrups religiøse tydning af sin teori om sansningen at illustrere denne proces. Hans analyse tager udgangspunkt i sansningens Førstehed, men ender i hypotesen om, at sansningens sansekvaliteter ikke stammer fra sansningen selv, men fra en skabende magt, der sanser universet og således er nødvendig for sansningen. ${ }^{29}$

Selv om det fortjener en detaljeret udfoldelse kan man tentativt konkludere, at Løgstrups religiøse spekulation er i overensstemmelse med Peirces opfattelse af 'the Neglected Argument':

It is that course of meditation upon the three Universes which gives birth to the hypothesis and ultimately to the belief that they, or at any rate two of the three, have a Creator independent of them, that I have throughout this article called the N.A. [Neglected Argument], because I think theologians ought to have recognized it as a line of thought reasonably productive of belief (EP 2:248).

29. Tilsvarende har hans analyse af tilintetgørelse og væren (Løgstrup 1978) fokus på Andethed og ender i en hypotese om en skabende magt, der opretholder væren, mens det er til. 